\title{
PENGGUNAAN MEDIA KANCING MAGNETIK UNTUK MENINGKATKAN KEMAMPUAN BERPIKIR KRITIS SISWA MATERI PERKALIAN BILANGAN BULAT
}

\author{
Rivo Nugroho \\ Pendidikan Luar Sekolah, Fakultas Ilmu Pendidikan Universitas Negeri Surabaya, rivonugroho@unesa.ac.id \\ Ris Tina Setyawati \\ Pendidikan Dasar, Program Pascasarjana, Universitas Negeri Surabaya, ristina2009@gmail.com
}

\begin{abstract}
Abstrak
Berdasarkan hasil observasi di SDN 2 Mulung Kecamatan Driyorejo Kabupaten Gresik khususnya di kelas V, guru hanya menekankan pembelajaran pada pencapaian kemampuan intelegensi sehingga kemampuan siswa untuk berpikir kritis pada materi perkalian bilangan bulat masih tergolong rendah. Hal ini disebabkan guru belum menemukan cara dan media yang dapat digunakan untuk menanamkan konsep perkalian bilangan bulat. Sehingga siswa masih menggunakan metode menghafal suatu konsep dan belum bisa memahami konsep tersebut. Hal ini menyebabkan kurang maksimalnya hasil belajar dan kemampuan berpikir kritis siswa. Pada penelitian ini, upaya yang dilakukan peneliti untuk meningkatkan kemampuan berpikir kritis siswa pada materi perkalian bilangan bulat adalah menggunakan media kancing-kancing magnetik.

Tujuan yang dicapai adalah mendeskripsikan aktivitas guru dalam menggunakan media kancing magnetik pada materi perkalian bilangan bulat, mendeskripsikan aktivitas siswa dalam menggunakan media kancing magnetik pada materi perkalian bilangan bulat, dan mendeskripsikan hasil peningkatkan kemampuan berpikir kritis siswa kelas V SDN 2 Mulung pada materi perkalian bilangan bulat dengan menggunakan media kancing magnetik.

Penelitian ini termasuk jenis Penelitian Tindakan Kelas (PTK). Berdasarkan jenis penelitian maka metode yang digunakan adalah metode deskriptif kualitatif dan deskriptif kuantitatif. Sesuai dengan metode maka teknik analisis data yang digunakan adalah deskriptif kualitatif untuk data observasi aktivitas guru dan siswa. Sedangkan data kuantitatif pada penelitian ini diperoleh dari hasil tes. Penelitian dilakukan dua siklus dan setiap siklus terdiri dari dua pertemuan.

Setelah peneliti menggunakan media kancing magnetik pada materi perkalian bilangan bulat, peneliti mendapatkan hasil yang memuaskan. Hasil penelitian menunjukkan bahwa adanya peningkatan nilai aktivitas guru pada siklus I sebesar 82,3\% dan pada siklus II meningkat menjadi 92,7\% dengan kategori sangat baik. Hasil observasi aktivitas siswa juga mengalami peningkatan dari $82,5 \%$ pada siklus I dan meningkat pada siklus II menjadi $92,5 \%$ dengan predikat sangat baik. Selain itu, dari hasil tes pada siklus I menunjukkan secara klasikal kemampuan berpikir kritis siswa mencapai 76,7\% dan pada siklus II meningkat menjadi 93,3\% dengan kategori sangat baik. Sehingga dapat disimpulkan bahwa dengan penggunaan media kancing magnetik dapat meningkatkan kemampuan berpikir kritis siswa pada materi perkalian bilangan bulat di kelas V SDN 2 Mulung Kecamatan Driyorejo Kabupaten Gresik.
\end{abstract}

Kata kunci: Media Kancing Magnetik, Berpikir Kritis, Perkalian Bilangan Bulat.

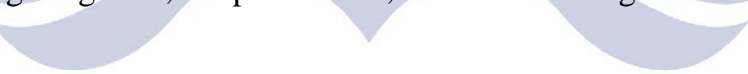

Based on the observation in SDN 2 Mulung Kecamatan Driyorejo Kabupaten Gresik especially for the fifth grade students, the teacher only focused on the learning to reach the intelligent ability so the ability of the student to think critically on integer multiplication was still low. In this research, the researcher tried to develop the students' critical thinking on integer multiplication by using magnetic buttons.

The purposes are to describe the activities of the teacher in using magnetic buttons on integer multiplication, to describe the activities of the students in using magnetic buttons on integer multiplication, and to describe the result of the improvement of students' critical thinking. This research includes of studies class action was obtained through observation and analyzed test by using descriptive qualitative technical analysis and descriptive quantitative. There were two cycles in this research, each cycle contained of two meetings.

The result of the research showed that there was an improvement of the teacher's activities value on cycle I for about $82,3 \%$ and on cycle II increased to be $92,7 \%$ with excellent category. The result of the students' activities also increased from $82,5 \%$ on cycle I to be $92,5 \%$ on cycle II with very good category. Beside that, from the result of the test on cycle I the ability of the students' critic thinking got $76,7 \%$ classically and on cycle II increased to be $93,3 \%$ with very good category. It could be concluded that by using magnetic buttons could improve the activities of the teacher and students.

Key words: Magnetic Buttons, Critical Thinking, Integer Multiplication 


\section{PENDAHULUAN}

Mata pelajaran matematika pada jenjang sekolah dasar merupakan pijakan awal untuk konsep matematika pada jenjang yang lebih tinggi. Sehingga dalam pengajaran matematika di sekolah dasar harus mampu untuk dijadikan dasar penalaran siswa dalam membantu menyelesaikan permasalahan dalam kehidupan seharihari serta kemampuan materi bilangan, simbol-simbol, serta mengembangkan sikap kritis, logis, disiplin, cermat, terbuka, optimis, dan menghargai matematika.

Keterampilan berpikir kritis siswa yang masih tergolong rendah menyebabkan perolehan hasil belajar siswa yang tidak optimal. Sebagai bukti adalah hasil pengamatan yang dilakukan peneliti pada proses pembelajaran di kelas materi perkalian bilangan bulat. Perolehan nilai belajar siswa yang masih rendah dapat dibuktikan dari hasil pre tes mata pelajaran matematika materi perkalian bilangan bulat. Dari hasil pre tes dapat dilihat bahwa masih banyak siswa yang nilainya berada di bawah ketentuan Kriteria Ketuntasan Minimal (KKM) yang ditetapkan oleh sekolah yaitu 65 .

Pada umumnya siswa kurang memahami konsep perkalian bilangan bulat yaitu terlihat dari ketidakmampuan siswa menyelesaikan soal perkalian bilangan bulat dengan benar terutama soal yang realistis. Siswa masih kebingungan dalam menentukan hasil dari perkalian tersebut positif ataukah negatif. Siswa juga kurang mampu menggunakan konsep tersebut untuk memecahkan masalah dalam kehidupan nyata yang berhubungan dengan konsep yang dimiliki. Siswa belum menguasai konsep perkalian bilangan bulat karena selama ini guru menganggap sulit menemukan cara untuk menanamkan konsep perkalian bilangan bulat. Guru juga kurang memberikan contoh yang nyata kepada siswa, bahkan lebih sering mengajar secara abstrak untuk materi yang diajarkan.

Memang pada dasarnya konsep-konsep dalam matematika itu abstrak, namun pada umumnya siswa berpikir dari hal-hal yang konkret menuju hal-hal yang abstrak. Menurut Haris, 2013: 448), karakteristik berpikir kritis, lebih meningkatkan karakteristik khususnya dalam menghadapi, memanfaatkan informasi, membedakan klaim yang rasional dan emosional, kemampuan menunjukkan analisis data, kemampuan berargumentasi, kemampuan menggunakan bukti. Untuk mengatasi masalah tersebut, maka salah satu jembatannya agar siswa mampu berpikir abstrak tentang matematika adalah dengan menggunakan media atau alat peraga. Sesuai dengan tingkat perkembangan intelektual anak SD yang masih dalam tahap operasional konkret, maka siswa SD dapat menerima konsep-konsep matematika yang abstrak melalui benda-benda konkret. Dengan menggunakan media kancing-kancing diharapkan dapat meningkatkan kemampuan berpikir kritis siswa pada materi perkalian bilangan bulat dan dapat membantu guru mengaitkan antara materi pelajaran dengan konteks keseharian siswa sehingga pembelajaran akan menjadi lebih bermakna.
Tujuan dari penelitian ini sebagai berikut: (1) mendeskripsikan aktivitas yang dilakukan oleh guru; (2) mendeskripsikan aktivitas yang dilakukan oleh siswa; (3) mendeskripsikan hasil peningkatan kemampuan berpikir kritis siswa kelas

\section{METODE}

Penelitian ini termasuk jenis Penelitian Tindakan Kelas (PTK). Penelitian ini menggunakan metode deskriptif kualitatif dan kuantitatif. Data kualitatif pada penelitian ini diperoleh dari hasil observasi aktivitas guru dan aktivitas siswa. Sedangkan data kuantitatif pada penelitian ini diperoleh dari hasil tes. Penelitian ini memaparkan data yang diperoleh secara alami mulai dari data sebelum tindakan, selama tindakan dan sesudah tindakan. Data yang diperoleh dianalisis menggunakan menggunakan rumus kuantitatif sederhana. Kemudian dideskripsikan atau dijabarkan dalam bentuk deskriptif kualitatif.

Subjek dalam penelitian ini adalah siswa kelas V SDN 2 Mulung Kecamatan Driyorejo Kabupaten Gresik. Siswa kelas V SDN 2 Mulung berjumlah 30 orang, yang terdiri dari 14 siswa laki-laki dan 16 siswa perempuan.

Menurut Indarti (2008: 31) "tahap dalam pelaksanaan penelitian tindakan kelas meliputi tahap perencanaan tindakan, pelaksanaan tindakan dan observasi, serta tahap analisis dan refleksi. Ketiga tahap dalam penelitian tindakan tersebut merupakan satu siklus, yaitu satu putaran kegiatan beruntun, dari tahap penyusunan rancangan sampai dengan refleksi, yang tidak lain adalah evaluasi".

Pada akhir tindakan harus dilakukan refleksi untuk mengetahui letak keberhasilan dan hambatan dari tindakan yang dilaksanakan pada setiap siklus. Data penelitian diperoleh dengan menggunakan teknik observasi dan tes. Data yang diperoleh dalam penelitian ini diolah dan dianalisis berdasarkan jenisnya yaitu hasil aktivitas guru dan siswa selama kegiatan pembelajaran.

Peneliti menggunakan media kancing magnetik untuk meningkatkan kemampuan berpikir kritis pada siswa pada pembelajaran materi operasi perkalian bilangan bulat. Media kancing magnetik yaitu media benda konkret berupa kancing berwarna (warna merah untuk bilangan positif dan dan warna putih untuk bilangan negatif) yang diberi magnet pada salah satu sisinya dan dapat ditempelkan pada papan magnetik yang terbuat dari seng, dan bisa diamati secara langsung oleh panca indera dengan cara melihat, mengamati, dan memegangnya secara langsung tanpa melalui alat bantu.

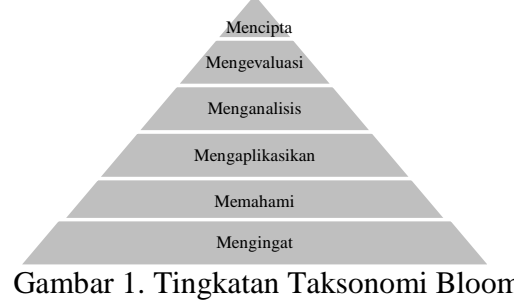

Untuk mengetahui tingkat kemampuan berpikir kritis siswa berdasarkan taksonomi Bloom dapat 
dikategorikan sebagai berikut:(a) Tingkat 1 (Tidak kritis), jika siswa hanya bisa mengerjakan soal yang membutuhkan kemampuan mengingat pengetahuan awal mereka saja dan belum bisa memahami pengetahuan tersebut.(b) Tingkat 2 (Kurang kritis), jika siswa mampu mengingat dan memahami pengetahuan yang mereka dapatkan (misalnya dengan menafsirkan, mencontohkan, mengklasifikasikan) tapi belum bisa mengaplikasikan pemikiran dan pengetahuan tersebut pada kehidupan nyata mereka.(c) Tingkat 3 (Cukup kritis), jika siswa bisa mengerjakan soal yang membutuhkan kemampuan mengingat, memahami dan mengaplikasikan pemikiran dan pengetahuan mereka pada kehidupan nyata tapi belum bisa menganalisis pengetahuan tersebut. (d) Tingkat 4 (Kritis), jika siswa mampu mengerjakan soal yang membutuhkan kemampuan mengingat, memahami, mengaplikasikan, dan sampai pada tahap menganalisis pengetahuan serta pemikiran mereka untuk memecahkan suatu masalah, serta dapat mengevaluasi. (e) Tingkat 5 (Sangat kritis), jika siswa memiliki kemampuan mengingat, memahami, mengaplikasikan, menganalisis, dan mengevaluasi serta sampai pada tahap mencipta maka dapat dikategorikan sangat kritis. Jadi siswa dikatakan sangat kritis apabila mereka sudah sampai pada tahap berpikir yang paling tinggi yaitu mencipta. Untuk menganalisis data hasil tes sesuai tingkat kemampuan berpikir kritis siswa secara klasikal menggunakan rumus :

$$
\text { Persentase }=\frac{\text { jumlah } \text { siswa sesuai tingkat kekritisan }}{\text { jumlah } \text { siswa keseluruhan }} \times 100 \%
$$

\section{Keterangan}

Persentase $=$ persentase siswa pada tiap tingkat kekritisan

Jumlah siswa sesuai tingkat kekritisan = banyaknya siswa yang mampu mencapai tiap tingkat kekritisan sesuai dengan Taksonomi Bloom.

Sedangkan untuk menganalisis data hasil tes kemampuan berpikir kritis siswa pada setiap tingkat kognitif dihitung dengan rumus persentase berikut ini:

$$
\text { Persentase }=\frac{\text { jumlah siswa yang menjawab benar }}{\text { jumlah } \text { siswa } \text { keseluruhan }} \times 100 \%
$$

\section{Keterangan}

Persentase $=$ Persentase siswa yang menjawab benar pada setiap tingkat kognitif

Jumlah siswa yang menjawab benar = banyaknya siswa yang mampu menyelesaikan atau menjawab soal dengan benar pada setiap tingkat kognitif

Tabel 1

\begin{tabular}{|c|c|c|}
\hline $\begin{array}{c}\text { Pencapaian } \\
\text { Tujuan } \\
\text { Pembelajaran }\end{array}$ & Kualifikasi & $\begin{array}{c}\text { Tingkat } \\
\text { Keberhasilan } \\
\text { Pembelajaran }\end{array}$ \\
\hline $85 \%-100 \%$ & Sangat baik & Berhasil \\
\hline & & Berhasil \\
\hline $65 \%-84 \%$ & Baik & Tidak berhasil \\
\hline $55 \%-64 \%$ & Cukup & Tidak berhasil \\
\hline $0 \%-54 \%$ & Kurang & \\
\hline
\end{tabular}

(Aqib, 2009:161)

\section{HASIL DAN PEMBAHASAN}

Dalam pembelajaran RPP dikembangkan dengan menggunakan model pembelajaran PBI (Problem Ba Instruction). Peneliti memilih model PBI dengan tuj 185 memacu semangat setiap siswa untuk aktif terlibat dalam kegiatan pembelajaran dan mengembangkan kemampuan berpikir siswa yang lebih tinggi dalam memecahkan masalah. Kasmurie (2010: 265) "This means students' critical thinking level can be improved by using a proactive method". Evaluasi pembelajaran yang dilakukan meliputi proses dan hasil belajar. Evaluasi proses yang dimaksud adalah aktivitas siswa selama proses belajar mengajar berlangsung, sedangkan evaluasi hasil belajar berupa soal tes kemampuan berpikir kritis siswa yang dilakukan pada akhir siklus.

Pada Siklus I, hasil analisis observasi aktivitas guru pada tiap aspek kemudian data disajikan dalam tabel hasil analisis observasi aktivitas guru sebagai berikut.

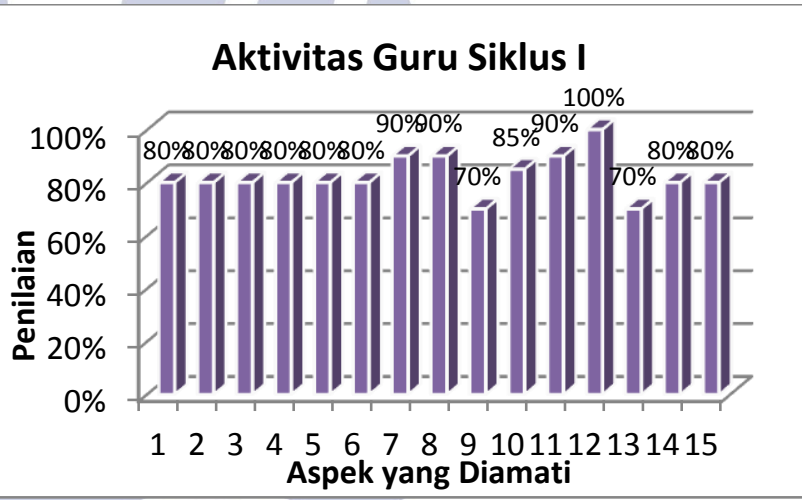

Berdasarkan diagram aktivitas guru dalam kegiatan pembelajaran meliputi: (1) penyampaian tujuan pembelajaran, (2) mengkonstruksi pengetahuan awal siswa, (3) memberi permasalahan yang berhubungan dengan bilangan bulat, (4) menampilkan media kancing magnetik untuk pemodelan, (5) mengorganisasikan siswa ke dalam kelompok belajar, (6) membagikan LKS dan media kancing magnetik kepada tiap kelompok, (7) membimbing siswa dalam kelompok untuk menyelesaikan LKS, (8) membimbing kelompok dalam menggunakan media kancing magnetik, (9) membimbing kelompok untuk mempresentasikan hasil kerja kelompok, (10) melaksanakan penilaian selama proses pembelajaran, (11) melakukan penilaian hasil LKS atau evaluasi di akhir pelajaran, (12) menyimpulkan materi pembelajaran, (13) memberi kegiatan tindak lanjut, (14) penilaian penampilan umum guru dalam pembelajaran, (15) serta melakukan komunikasi secara efektif. Berdasarkan hasil observasi aktivitas guru dalam melaksanakan pembelajaran pada siklus I sudah baik. Hal ini dilihat dari nilai persentase aktivitas guru secara keseluruhan sudah mencapai kategori baik dengan ratarata $82,3 \%$. 
Pada Siklus I hasil analisis observasi aktivitas siswa pada tiap aspek disajikan dalam bentuk diagram batang aktivitas siswa.

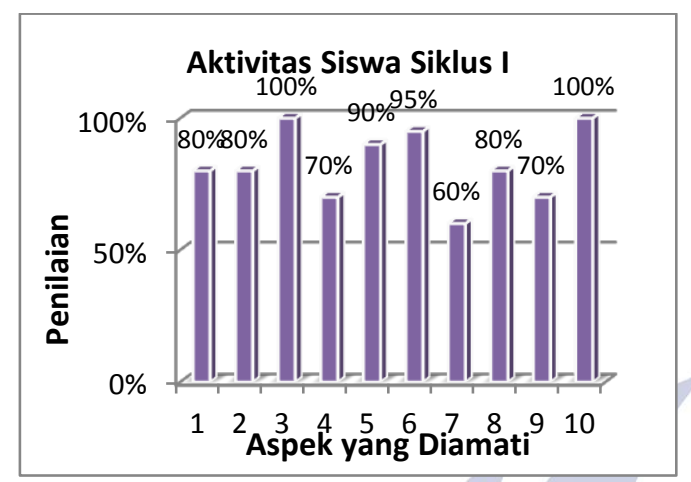

Berdasarkan diagram aktivitas siswa dalam kegiatan pembelajaran meliputi: (1) memperhatikan penjelasan guru, (2) menyelesaikan permasalahan yang berhubungan dengan perkalian bilangan bulat, (3) memperhatikan guru dalam mendemonstrasikan penggunaan media kancing magnetik, (4) bertanya kepada guru tentang cara memperagakan perkalian bilangan bulat menggunakan media dan menanyakan materi yang belum dimengerti, (5) membentuk kelompok belajar, (6) melakukan penyelidikan , (7) menyelesaikan masalah yang ada dalam LKS, (8) memberi kesempatan kepada teman (anggota kelompok) untuk menggunakan media kancing magnetik, (9) mempresentasikan dan memperagakan hasil kerja kelompok dengan menggunakan media kancing magnetik, dan memberikan tanggapan terhadap kelompok lain yang presentasi, serta (10) merefleksi materi pembelajaran bersama guru. Dari hasil pengamatan pada kegiatan pembelajaran siklus I, aktivitas yang dilakukan oleh siswa pada saat pembelajaran perkalian bilangan bulat dengan menggunakan media kancing magnetik sudah baik. Hal ini dilihat dari persentase aktivitas siswa secara keseluruhan sudah mencapai kategori baik dengan ratarata nilai $82,5 \%$.

Pada Siklus I hasil analisis tes kemampuan berpikir siswa pada tiap tingkat kekritisan kemudian data disajikan dalam bentuk diagram lingkaran sebagai berikut:

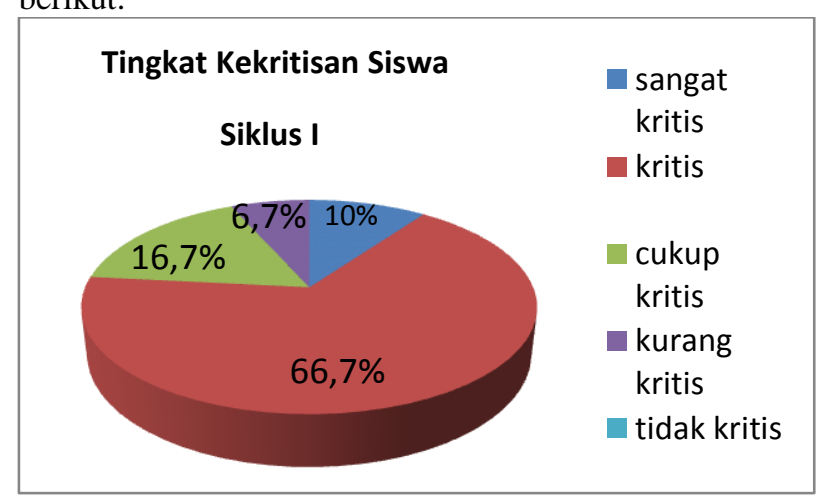

Dari hasil tes kemampuan berpikir kritis siswa diperoleh data bahwa dari 30 siswa kelas V, sebanyak 3 siswa sudah mampu mencapai tingkat kemampuan berpikir sangat kritis, sebanyak 20 siswa sudah mencapai tingkat berpikir kritis, 5 orang siswa mencapai tingkat berpikir cukup kritis dan 2 siswa masih berada pada tingkat berpikir kurang kritis.

Dari hasil analisis tes pada setiap tingkat kognitif kemudian data disajikan dalam bentuk diagram batang sebagai berikut:

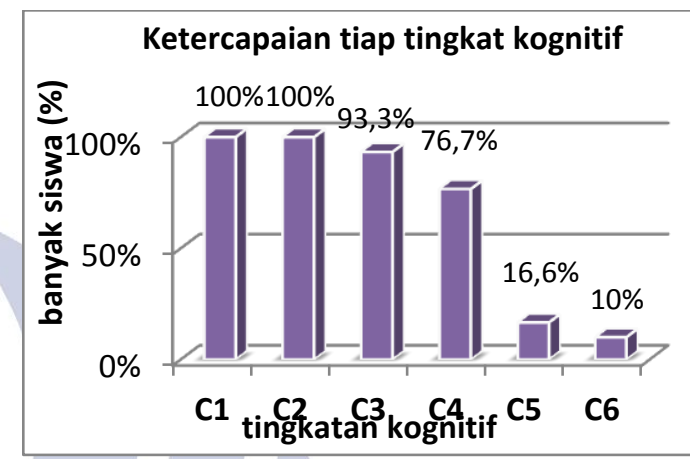

Berdasarkan data hasil tes pada siklus I, menunjukkan bahwa 30 siswa mampu menyelesaikan soal $\mathrm{C} 1$ (mengingat) dan $\mathrm{C} 2$ (memahami) dengan benar, 28 siswa mampu menyelesaikan soal C3 (mengaplikasi), 23 siswa mampu menyelesaikan soal C4 (menganalisis), 5 siswa mampu menyelesaikan soal C5 (mengevaluasi) dan hanya 3 siswa yang mampu menyelesaikan soal C6 (mencipta).

Analisis hasil tes kemampuan berpikir kritis siswa pada materi perkalian bilangan bulat dengan menggunakan media kancing magnetik, belum memenuhi indikator keberhasilan karena hanya $76,7 \%$ yang sudah mencapai tingkat kritis. Sedangkan indikator keberhasilan yang harus dicapai yaitu $80 \%$. Dari hasil analisis tiap tingkat kognitif $80 \%$ siswa belum mampu menyelesaikan soal $\mathrm{C} 4$. Berdasarkan hasil refleksi di akhir siklus I, perlu dilakukan siklus II.

Pada Siklus II proses pembelajaran pada menggunakan model pembelajaran PBI (Problem Based Instruction). Peneliti memilih model PBI dengan tujuan memacu semangat setiap siswa untuk aktif terlibat dalam kegiatan pembelajaran dan mengembangkan kemampuan berpikir siswa yang lebih tinggi dalam memecahkan masalah. Hasil analisis observasi aktivitas guru pada tiap aspek disajikan dalam bentuk diagram batang sebagai berikut: 


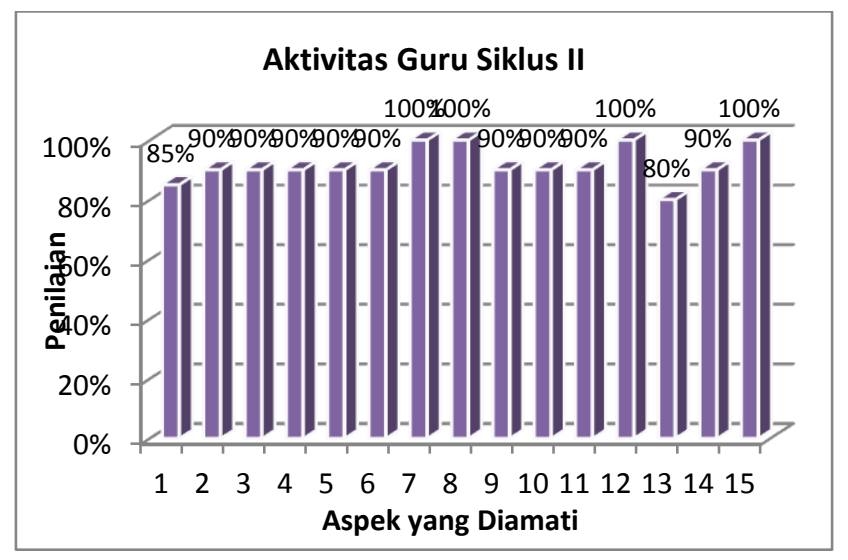

Berdasarkan diagram aktivitas guru dalam kegiatan pembelajaran meliputi: (1) penyampaian tujuan pembelajaran, (2) mengkonstruksi pengetahuan awal siswa, (3) memberi permasalahan yang berhubungan `engan bilangan bulat, (4) menampilkan media kancing

186 agnetik untuk pemodelan, (5) mengorganisasikan siswa ke dalam kelompok belajar, (6) membagikan LKS dan media kancing magnetik kepada tiap kelompok, (7) membimbing siswa dalam kelompok untuk menyelesaikan LKS, (8) membimbing kelompok dalam menggunakan media kancing magnetik, (9) membimbing kelompok untuk mempresentasikan hasil kerja kelompok, (10) melaksanakan penilaian selama proses pembelajaran, (11) melakukan penilaian hasil LKS atau evaluasi di akhir pelajaran, (12) menyimpulkan materi pembelajaran, (13) memberi kegiatan tindak lanjut, (14) penilaian penampilan umum guru dalam pembelajaran, (15) serta melakukan komunikasi secara efektif. Pada kegiatan pembelajaran siklus II, aktivitas guru dalam mengelola kelas dan mengajarkan materi perkalian bilangan bulat dengan menggunakan media kancing magnetik sudah sangat baik. Hal ini dilihat dari persentase aktivitas guru secara keseluruhan sudah mencapai kategori sangat baik dengan rata-rata 91,7\%.

Hasil analisis observasi aktivitas siswa pada tiap aspek kemudian data disajikan dalam bentuk diagram batang sebagai berikut:

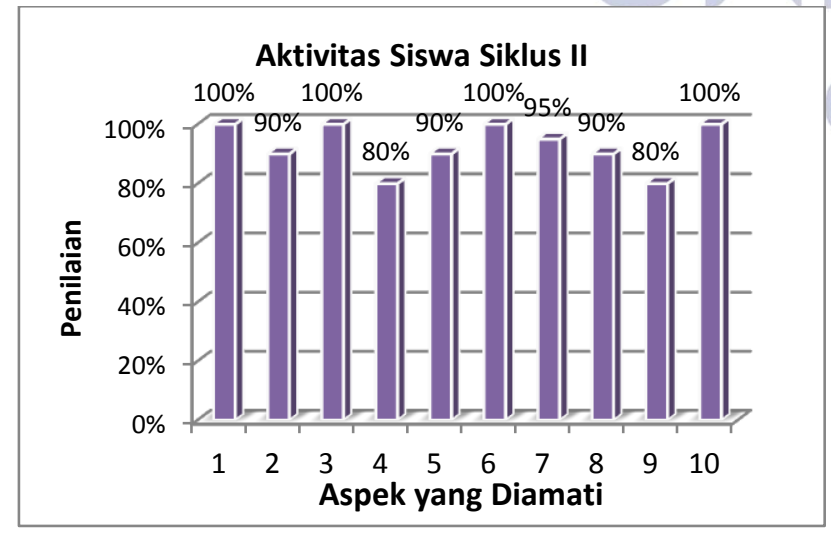

Berdasarkan diagram aktivitas siswa dalam kegiatan pembelajaran meliputi: (1) memperhatikan penjelasan guru, menyelesaikan permasalahan yang berhubungan dengan perkalian bilangan bulat, (2) memperhatikan guru dalam mendemonstrasikan penggunaan media kancing magnetik, (3) bertanya kepada guru tentang cara memperagakan perkalian bilangan bulat menggunakan media, (4) menanyakan materi yang belum dimengerti, (5) membentuk kelompok belajar, (6) melakukan penyelidikan dan menyelesaikan masalah yang ada dalam LKS, (7) memberi kesempatan kepada teman (anggota kelompok) untuk menggunakan media kancing magnetik, (8) mempresentasikan dan memperagakan hasil kerja kelompok dengan menggunakan media kancing magnetik, (9) dan memberikan tanggapan terhadap kelompok lain yang presentasi, serta (10) merefleksi materi pembelajaran bersama guru. Berdasarkan hasil pengamatan aktivitas siswa saat bertanya kepada guru tentang cara memperagakan perkalian bilangan bulat menggunakan media dan menanyakan materi yang belum dimengerti persentase yang diperoleh sebesar $80 \%$ dengan kategori baik. Hal ini dikarenakan hanya sudah banyak yang mengajukan pertanyaan kepada guru, tidak seperti pada tindakan siklus I yaitu siswa masih malu dan takut untuk bertanya.

Hasil analisis tes kemampuan berpikir siswa pada tiap tingkat kekritisan kemudian data disajikan dalam bentuk diagram sebagai berikut:

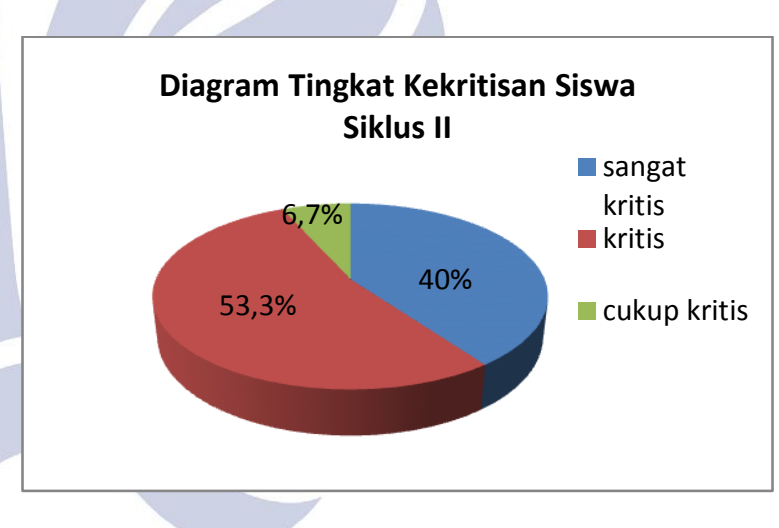

Pada gambar diagram lingkaran menunjukkan bahwa tingkat kemampuan berpikir kritis siswa pada pembelajaran siklus II sudah mencapai 93,3\% dan dapat dikategorikan sangat baik Berdasarkan data hasil tes pada siklus II, menunjukkan bahwa 30 siswa mampu menyelesaikan soal C1 (mengingat), C2 (memahami) dan soal C3 (mengaplikasikan) dengan benar, 28 siswa mampu menyelesaikan soal C4 (menganalisis), 16 siswa mampu menyelesaikan soal C5 (mengevaluasi) dan ada 13 siswa yang mampu menyelesaikan soal C6 (mencipta). Dari hasil analisis tes pada setiap tingkat kognitif kemudian data disajikan dalam bentuk diagram batang sebagai berikut: 


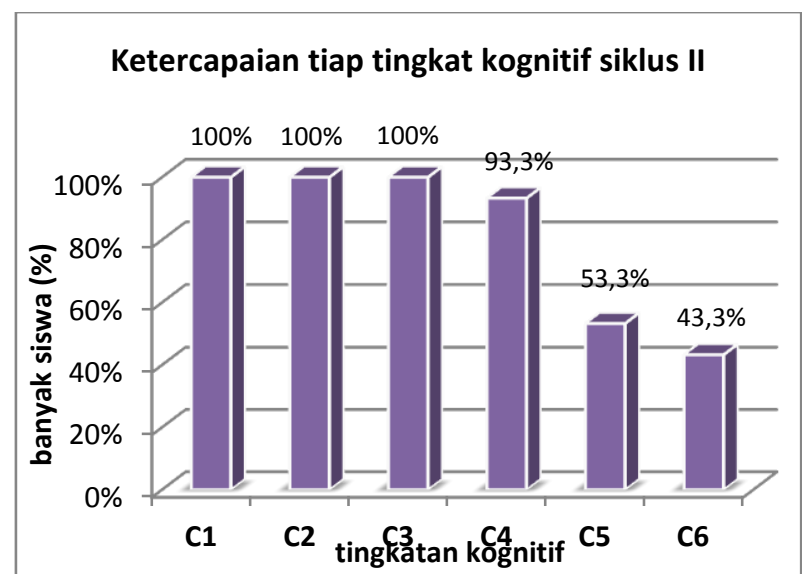

Berdasarkan hasil observasi aktivitas guru di siklus II menunjukkan bahwa persentase nilai yang diperoleh guru sebesar $91,7 \%$. Nilai tersebut menunjukkan bahwa guru sangat baik dalam melaksanakan pembelajaran pada materi perkalian bilangan bulat dengan menggunakan media kancingkancing magnetik. Dibandingkan dengan siklus I persentase nilai aktivitas guru pada siklus II mengalami peningkatan sebesar 9,4\%. Perbandingan nilai aktivitas guru pada siklus I dan II dapat dilihat pada diagram berikut:

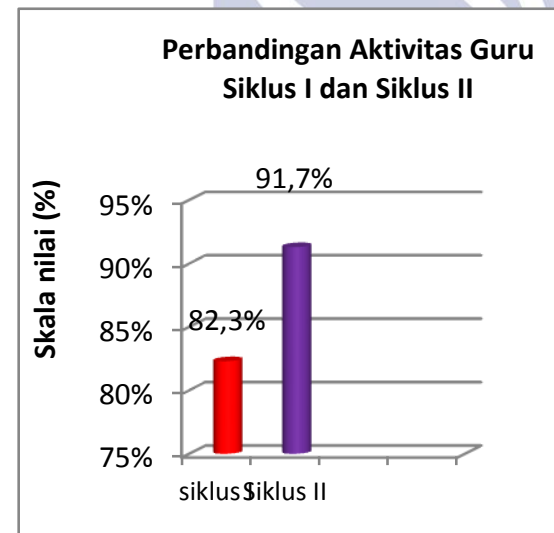

Kegiatan pembelajaran pada materi perkalian bilangan bulat dengan menggunakan media kancingkancing magnetik di siklus II menunjukkan bahwa persentase aktivitas siswa dalam mengikuti pembelajaran mencapai $92,5 \%$ dengan kategori sangat baik. Hal ini menunjukkan bahwa persentase nilai aktivitas siswa pada siklus II meningkat dibandingkan dengan siklus I. Perbandingan nilai aktivitas siswa pada siklus I dan siklus II dapat dilihat pada diagram berikut:

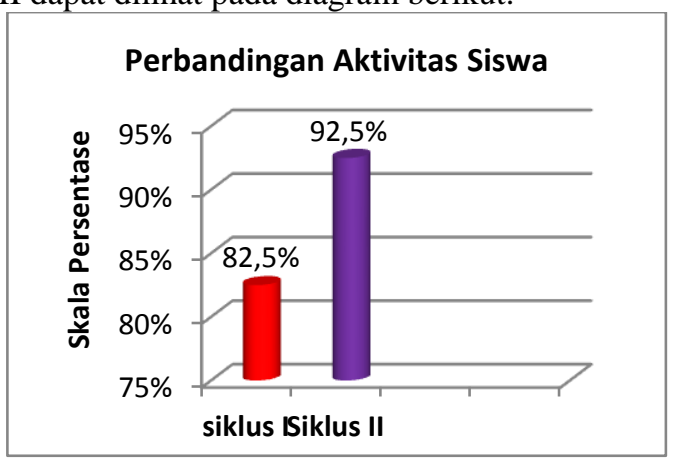

Berdasarkan diagram dapat dilihat bahwa aktivitas siswa dalam pembelajaran dengan menggunakan media kancing-kancing magnetik mengalami peningkatan sebesar $10 \%$. Hal ini dapat dilihat dari nilai persentase aktivitas siswa pada siklus I sebesar $82,5 \%$ dengan kategori baik dan mengalami peningkatan pada siklus II menjadi 92,5\% dengan kategori sangat baik.

Perbandingan tingkat kognitif yang dicapai siswa di siklus I dan siklus II pada pembelajaran perkalian bilangan bulat dapat dilihat pada diagram berikut

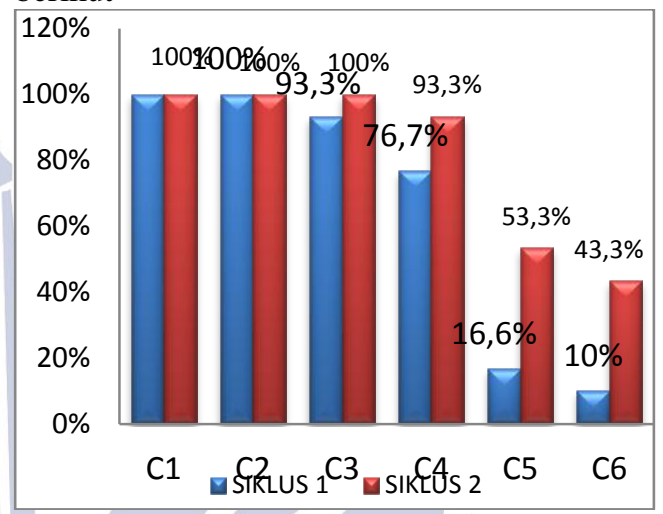

Perbandingan tingkat kemampuan berpikir siswa di siklus I dan siklus II pada pembelajaran perkalian bilangan bulat dengan menggunakan media kancingkancing magnetik dapat dilihat pada diagram berikut:

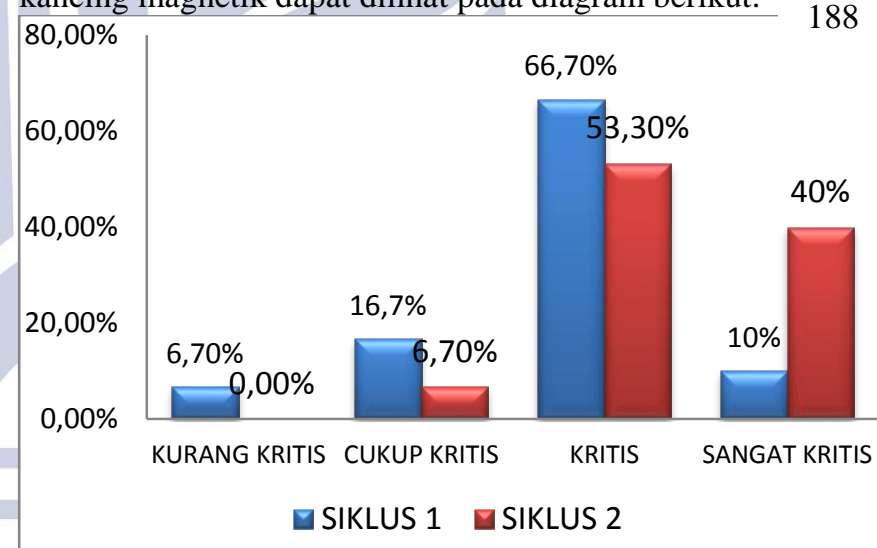

Berdasarkan diagram dapat dilihat bahwa hasil analisis tes kemampuan berpikir kritis siswa pada siklus II meningkat sebanyak $16,6 \%$. Hal ini dapat dilihat dari hasil tes pada siklus I yang mencapai tingkat kritis sebanyak 76,7\% siswa dengan kategori baik dan pada siklus II mencapai 93,3\% dan dapat dikategorikan sangat baik.

Dilihat dari semua hasil yang telah diperoleh pada saat kegiatan pembelajaran dengan menggunakan media kancing-kancing magnetik pada perkalian bilangan bulat dari siklus I sampai dengan siklus II sangatlah jelas bahwa penggunaan media kancing-kancing magnetik dapat meningkatkan kemampuan berpikir kritis siswa pada materi perkalian bilangan bulat.

\section{PENUTUP}

\section{Simpulan}


Berdasarkan hasil penelitian yang telah dideskripsikan pada bab sebelumnya maka dapat disimpulkan bahwa kemampuan berpikir kritis siswa kelas $\mathrm{V}$ mengalami peningkatan setelah menggunakan media kancing magnetik selama kegiatan pembelajaran pada materi perkalian bilangan bulat. Peningkatan kemampuan berpikir kritis siswa dapat dilihat dari analisis hasil tes siswa pada siklus I yaitu jumlah siswa yang sudah mencapai tingkat kritis dapat dikategorikan baik. Dan mengalami peningkatan pada siklus II dengan kategori sangat baik. Hal ini menunjukkan bahwa dengan menggunakan media kancing magnetik pada materi perkalian bilangan bulat dapat meningkatkan kemampuan berpikir kritis siswa.

\section{Saran}

Dengan memperhatikan hasil yang diperoleh pada penelitian ini, maka disarankan para guru agar menggunakan media pembelajaran dalam kegiatan belajar mengajar. Salah satu dari media yang dapat digunakan dalam kegiatan pembelajaran khususnya untuk meningkatkan kemampuan berpikir kritis siswa pada materi perkalian bilangan bulat adalah media kancing magnetik. Pembelajaran dengan menggunakan media kancing magnetik dapat memberikan motivasi dan minat belajar siswa, serta dapat membantu siswa untuk menemukan konsep dalam perkalian bilangan bulat, yang pada akhirnya dapat meningkatkan kemampuan berpikir kritis siswa dan penguasaan materi siswa. Dengan kemampuan berpikir kritis yang terasah maka para siswa akan mampu untuk menciptakan hal-hal baru yang inovatif yang menunjang dalam perkembangan Ilmu Pengetahuan dan Teknologi (IPTEK).

\section{DAFTAR PUSTAKA}

Arikunto, Suharsimi. 2010. Prosedur Penelitian Suatu Pendekatan Praktik. Jakarta: PT Rineka Cipta.

Aydin, Utkun, Behiye Ubuz. (2014)Predicting undergraduate students' mathematical thinking about derivative concept: A multilevel analysis of personal and institutional factors. Science Direct Learning and Individual Differences. Doi: 32 (2014) 80-92.

Aqib, Zaenal, dkk. 2009. Penelitian Tindakan Kelas. Bandung: Yrama Widya.

Arsyad, Azhar. 2011. Media Pembelajaran. Jakarta: Rajawali Pers.

Djamarah, Syaiful Bahri. 2000. Guru dan Anak Didik Dalam Interaksi Edukatif. Jakarta: PT Rineka Cipta.

Djamarah, Syaiful Bahri. 2013. Strategi Belajar Mengajar. Jakarta: PT Asdi Mahasatya.
Filsaime, Dennis. 2008. Menguak Rahasia Berpikir Kritis dan Kreatif. Jakarta: Prestasi Pustakaraya.

Gelersteina, Damián, Rodrigo $\mathrm{R}$.\& Miguel Nussbaumb.(2016) Designing and implementing a test for measuring critical thinking in primary school. Science Direct Thinking Skills and Creativity. Doi: 1871-1871/@ 2016 Elsevier Ltd. All rights reserved

Haris, Yosaphat N. Dkk. Pengembangan Berpikir Kritis Dalam Pembelajaran Pendidikan Kewarganegaraan Menggunakan Project Citizen Cakrawala Pendidikan.: November 2013, Th. XXXII, No. 3: 444-449

Indarti, Titik. 2008. Penelitian Tindakan Kelas dan Penulisan Ilmiah. Surabaya: FBS Universitas Negeri Surabaya.

Kurikulum Tingkat Satuan Pendidikan (KTSP). 2006. Mata Pelajaran Matematika Untuk Tingkat SD/MI. Jakarta: Depdiknas.

Kasmurie, Awg K. Abdul R.A\&Ahmad A. S. (2010). The Effectiveness Of Inquiry Teaching In Enhancing Students'Critical Thinking. Procedia Social And Behavioral Sciences. Doi:10.1016/J.Sbspro.2010.10.037. 264-273

Muhsetyo, Gatot. 2007. Pembelajaran Matematika SD Jakarta: Universitas Terbuka

Mulyasa, E. 2010. Praktik Penelitian Tindakan Kelas. Bandung: PT Remaja Rosdakarya.

Rajagukguk, Waminton and Erlinawaty S. (2015). Problem-Based Mathematics Teaching Kits Integrated With Ict To Improve Students' Critical Thinking Ability In Junior High Schools In Medan Cakrawala Pendidikan: Oktober 2015, Th. XXXIV, No. 3

Sitorus, Jonni, Masrayati. (2016). Implementationof Realistic Mathematics Education. Science Direct Thinking Skills and Creativity. Doi: 22 (2016) 111120

Van de Walle, J.A. 2008. Matematika sekolah Dasar dan Menengah Jilid 2. Jakarta: Erlangga.

Wenno, Izaak, dkk. (2016). Analisis Kesulitan Belajar Dan Pencapaian Hasil Belajar Siswa Melalui Strategi Pembelajaran Inkuiri. Cakrawala Pendidikan: Oktober 2016, Th. XXXV, No. 3. 378-385. 